Универзитет уметности у Београду, Факултет ликовних уметности - Одсек за теорију уметности, Београд;

Друштво психолога Србије, Београд

DOI 10.5937/kultura1858213F

УДК 316.644:371.123.011.3051:73/76(497.11)"2014/2017"

$371.134 / .136$

оригиналан научни рад
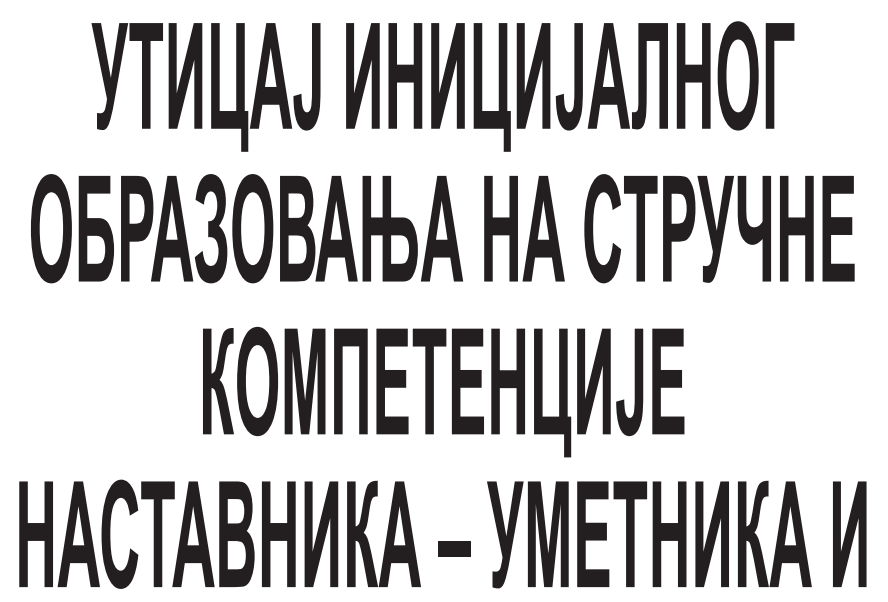

HАСТАВНИКА- -НЕУМЕТНИКА

УНАСТАВИ ТИКОВНЕ

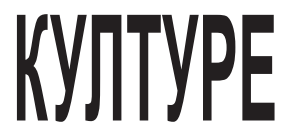

Сажетак: Полазећи од различитих програмских садржаја матичних факултета за област уметности и програма учитељских факултета, као и компетенција које будући наставници стичу на овим студијским програмима, сагледаван је утицај фактора као што је иницијално образовање наставника на степен креативности, односно дивергентног, креативног мичьења, као и ликовно-обликовни аспекти који се сагледавају кроз иртеж, доводећи чињенице које су утврђене у однос са компетенцијама наставника - уметника (наставника ликовне културе) и наставника - неуметника (наставника разредне наставе) за реализачију васпитно- 
образовних ичиљева, задатака, садржаја наставног предмета ликовна култура у основној школи и могућих реперкусија на креативни развој ученика. Истраживање је спроведено на узорку од три стотине тридесет два (332) наставника из тринаест (13) градова Србије. Карактеристике креативног, дивергентног мииљења праћене су на основу показатеља преузетих из стандардизованог истраживачког инструмента под називом: Модификовани креативни тест Вилијамса, а за праћење ликовно-обликовних аспеката иртежа креиран је посебан инструмент. На основу разлика које се јављају у погледу карактеристика ликовног израза и у зависности од инииијалног образовања у области ликовне уметности, односно ликовне педагогије, идентификоване су статистички значајне разлике између ове две популачије указујући на потребу постављаюа нових хипотеза, посебно у даљим истраживағима компетенција запослених у образовању за остваривање примарних ичьева наставног предмета ликовна култура, а посебно утицаја на креативни развој ученика у основној школи, као и иницијалног образовања и стицања компетенција за професију наставника у специфичним областима, као ито је ликовна уметност.

Кључне речи: наставник, учител, иницијално образовање, настава ликовне културе, ликовна педагогија, креативност

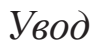

Последњих деценија се посвећује посебна пажња креативности у образовању, посебно када говоримо о најмлађима, те се истражују различити методички модели и приступи у неговању и развијању креативних способности деце и младих током формалног образовања. Ипак, резултати истраживања у овом домену показују опадање креативности по различитим компонентама, барем када се говори о дечјем ликовном стваралаштву, упркос напорима стручњака да унапреде овај сегмент васпитно-образовног рада. Полемике у стручној јавности о погодним приступима неговању креативности деце кроз школско образовање не недостају, али нам актуелна васпитно-образовна пракса говори нешто сасвим друго. На пример, у истраживањима креативности и ликовног језика код предшколаца, показало се да различити модели и приступи имају извесних реперкусија на дечји креативни развој, односно да су управо методички модели и рад наставника, фактор који утиче на те разлике. ${ }^{1}$

У другом истраживању, резултати предшколаца из Београда на тесту креативног, дивергентног мишљења које се сагледава кроз цртеж, поређени су са резултатима предшколаца

1 Филиповић, С. (2009) Развој схватања о дечјем ликовном стваралаштву и могућностима васпитно-образовног деловања на њега, докторска дисертација: Академија умјетности, Универзитет у Бањој Луци. 
у региону Санкт Петербурга (истраживање је обухватило укупно 1300 деце предшколског узраста 5-7 година), где су добијене статистички значајне разлике у корист деце из Србије. Као основни фактор који утиче на те разлике, показали су се програми, односно методика рада, односно приступ васпитача у неговању креативности, при чему су руски програми више окренути ка академским, високоструктурираним моделима, за разлику од наших, превасходно когнитивно развојних програма. ${ }^{2}$

Постоје многи показатељи који иду у прилог опадању креативности са узрастом. Фактор школа, односно програм, односно наставник који остварује програм, био је предмет и бројних истраживања Богомила Карлавариса (1970), који је указао на мањкавости у приступу неговања креативних потенцијала ученка у основној школи, посебно у нижим разредима, као и да су компетенције наставника један од кључних фактора тих разлика, што иде у прилог актуелним програмима на наставничким факултетима и разлика у стеченим компетенцијама наставника за рад у области наставе ликовне културе.

У наставној пракси, примећено је да учитељи и васпитачи веће тежиште стављају на знања о ликовним техникама и вештинама њихове примене у ликовном раду, као и формалним аспектима дечјег ликовног рада, док наставници ликовне културе више обраћају пажњу на контекст рада, ликовну поруку, јединство форме и садржаја, индивидуалну поетику, експресивност и иконографију, као предуслов за култивисање ликовног језика, развој естетских критеријума и креативности, као компоненте личности. ${ }^{3}$ Кудрјавцев и сарадници ${ }^{4}$ такође значајну одлику дечје креативности - дете види цело пре појединачног. Дакле, овде се дечји ликовни израз не посматра само као спонтано изражавање доживљаја детета и спонтано сазнање о предметима и појавама света, већ кроз целовитост дететове личности и систематизоване утицаје који доводе до развоја његових креативних способности. ${ }^{5}$

Говорећи о наставничким компетенцијама, важно је позвати се на званичан документ Стандарди компетенщија за

2 Janjević, V., Filipović, S. i Tunik, E. (2013) Uporedna analiza razvoja kreativnog mišljenja predškolaca u Peterburgu i Beogradu, Nova škola, VIII (2), str. 93-102, Bijeljina: Pedagoški fakultet.

3 Филиповић, С. (2016) Методичка пракса ликовних педагога, Београд: Факултет ликовних уметности.

4 Кудрявцев, В. Т., Уразалиева, Г. К. и Кириллов, И. Л. (2005) Личносный рост ребенка в дошколном образовании, Москва: Макспресс.

5 Панић, В. (2005) Психологија и уметност, Београд: Завод за уџбенике и наставна средства. 
професију наставника и юиховог професионалног развоја, ${ }^{6}$ где се кроз четири категорије компетенција (К1, К2, К3, К4), између осталих, појављује и захтев везан за развој креативности, критичког, аналитичког и дивергентног мишљења, као и креативну продукцију кроз подстицање креативности и иницијативе ученика.

Званични програми, односно програмски садржаји наставног предмета ликовна култура у основним школама у Србији подразумевају област ликовних уметности, као и њене дисциплине, које су структуриране према следећим садржајима: теорија форме (ликовни језик - ликовни елементи и принципи компоновања); ликовни медији (ликовна подручја/медији, ликовне, средства и материјали); уметничко наслеђе (садржаји из светске и националне културне баштине и народне традиције од праисторије до данас); теорија уметности (законитости ликовног обликавања, иконографије, ликовне поетике, естеског процењивања и др.); ликовно-уметничка пракса (самосталан истраживачки рад у ликовним медијима и креативна продукција). Сви ови наведени садржаји су део акредитованих студијских програма основних, мастер и докторских студија уметничких факултета различитих универзитета у Србији (Универзитет уметности у Београду, Универзитет у Новом Саду, Универзитет у Крагујевцу, Универзитет у Нишу и Универзитет у Приштини са седиштем у Косовској Митровици), који поред уметничких компетенција обезбеђују и наставничке кроз теоријске предмете из поља друштвено-хуманистичких наука, педагошко-андрагошких дисциплина, а које према Члану 8 Закона о основама система образовања и васпитања, ${ }^{7}$ задовољавају прописаних 36 ЕСПБ (ППМ предмета).

За разлику од уметничких факултета, учитељски факултети, као и високе струковне школе за образовање васпитача развијају компетенције студента - будућих васпитача и наставника за рад са предшколском децом, као и ученицима нижих разреда основне школе, стичући стручна знања из широког опсега области и дисциплина. Између осталог, садржаји програма ових неуметничких факултета, на основним и мастер студијама предвиђају стицање компетенција из уметничких дисциплина. Анализа ових програма показује сразмерно мали број садржаја који су превасходно засновани на обуци примене ликовних медија у настави, изостављајући способност самосталне креативне продукције заснованој

6 Стандарди компетенција за професију наставника и њиховог професионалног развоја (2011) Београд: ЗУОВ.

7 Закон о основама система образовања и васпитања (2013) Службени гласник РС, бр. 72/2009, 52/2011 и 55/2013. 
на примарним знањима, вештинама, ставовима и способностима који се стичу у оквиру иницијалног образовања студената на уметничким факултетима, будућих наставника ликовне културе. Томе у прилог треба додати и разлике у селекцији кандидата при упису на уметничке и неуметничке факултете, који битно одређују и компетенције свршених студента - будућих наставника у матичиној области ликовне уметности као разлике међу њима, сразмерно програмским садржајима на студијским програмима уметничких и неуметничких факултета.

Претпоставке су да, без обзира што се у нашем образовном систему примат даје стеченим формалним компетенцијама за професију наставника, да се у образовној пракси ипак идентификује доминација имплицитне педагогије у области наставе ликовне културе. Узимајући у обзир неуједначеност програма иницијалног образовања наставника, васпитача и учитеља у области ликовног васпитања и образовања, као и резултате бројних истраживања, отворила су се и питања везана за факторе који утичу на овако негативан тренд у постигнућима деце у домену креативне продукције, а посебно наставничких компетенција за остваривање примарних циљева наставног предмета ликовна култура у основној школи.

\section{Пројекат истраживана}

Полазећи од тенденција савремене наставе да креативни концепт буде заступљенији у школским курикулумима, методикама наставних предмета које подржавају креативност, посебно наставе ликовне културе у нижим и вишим разредима основне школе, у истраживању се пошло од следећих питања:

- Да ли иницијално образовање наставника ликовне културе и учитеља даје адекватну основу за реализацију циљева, задатака и садржаја наставног предмета ликовна култура, а у складу са Стандардима компетенција за професију наставника (ЗУОВ 2011)?

- Да ли постоје разлике у креативним постигнућима између популације наставника-уметника (наставника ликовне културе) и наставника-неуметника (наставника разредне наставе) кроз одговор на ликовне задатке који подразумевају: креативно, дивергентно мишљење и ликовно-обликовни израз?

- У ком степену наставници - уметници и наставници - неуметници примењују компетенције стечене на иницијалном образовању за професију наставника? 
- Да ли степен креативности и ликовно-обликовних аспеката у ликовном раду наставника (предметне или разредне наставе), а који представљају основу ликовне писмености, може бити фактор који утиче на компетенције наставника дефинисаних Стандрадима компетенција за професију наставника ${ }^{8}$ за реализацију циљева наставног предмета ликовна култура, а који се примарно односе на развој креативности и стваралачког изражавања?

- Да ли разлике у селекцији кадра при упису на матичне факултете (на пример, уметнички факултети који образују и будуће предметне наставнике ликовне културе и учитељски факултети који образују будуће наставнике разредне наставе) и разлике у иницијалном образовању могуће амортизовати, односно смањити и на који начин?

Очекивања у овом истраживању су била да ће на ликовни задатак ,доврши цртеж”, испитаници употребити:

- изражајне елементе користећи ликовни језик и креативно, дивергентно мишљење;

- знања стечена кроз иницијално образовање за наставну област ликовне уметности (теорија форме, теорија уметности, уметничко наслеђе, ликовне технике и материјали, ликовно-уметничка пракса и креативно изражавање);

- знања и компетенције стечене кроз иницијално образовање за наставни предмет ликовна култура (циљеви, задаци, садржаји, средства, медији) и методику наставе ликовне културе.

\section{Методолошки аспект истраживања}

\section{Проблем истраживања}

Основни проблем од кога се пошло у истраживања јесте сагледавање утицаја фактора као што је иницијално образовање наставника на степен креативности, односно дивергентног, креативног мишљења које се сагледава кроз цртеж, као и ниво ликовно-обликовних аспеката (основе ликовне писмености) доводећи чињенице које су утврђене у однос са компетенцијама наставника за реализацију васпитнообразовних циљева, задатака, садржаја наставног предмета

8 Стандарди компетенщија за професију наставника и њиховог професионалног развоја (2011) Београд: ЗУОВ. 
ликовна култура у основној школи и могућих реперкусија на креативни развој ученика.

\section{Циљ и задаџи истраживана}

Основни циљ истраживања је идентификовање степена примене стечених компетенција за област ликовне уметности/ културе на иницијалном образовању, као и могућих разлика у зависности од врсте студија, селекције при упису и програмских садржаја из ликовне уметности и културе.

Основни задатак је био да се испитају односи, пре свега, између компетенција наставника ликовне културе и учитеља, односно наставника-уметника и наставника-неуметника, при чему је узет у обзир фактор иницијално образовање за професију наставника, за који се претпоставља да би разлике међу њима требало да имају реперкусије и на дечји креативни развој у настави ликовне културе: 1. Утврдити да ли постоје разлике у креативности наставника-уметника (наставника ликовне културе) и наставника-неуметника (наставника разредне наставе); 2. Утврдити да ли постоје разлике у ликовно-обликовним аспектима цртежа као основе ликовне писмености код наставника-уметника (наставника ликовне културе) и наставника-неуметника (наставника разредне наставе).

\section{Хипотезе}

Хипотезе истраживања гласе:

1. „Очекује се да ће постојати разлике у тесту креативности, односно дивергентног, креативног мишљења, наставника-уметника (наставника ликовне културе) и наставниканеуметника (наставника разредне наставе), а у зависности од њиховог иницијалног образовања за професију наставника." Ова хипотеза се заснива на најчешћим резултатима досадашњих истраживања. ${ }^{9}$

2. „Очекује се да ће постојати разлике у ликовно-обликовном аспекту цртежа наставника-уметника (наставника ликовне културе) и наставника-неуметника (наставника разредне наставе) а у зависности од њиховог иницијалног образовања за професију наставника.” Ова хипотеза је заснована на ставу да формално универзитетско образовање за професију наставника ликовне културе на уметничким факултетима утиче на разлике у компетенцијама наставника-уметника

9 Bojanović, R. i Đurišić-Bojanović, M. (2016) Efekti vežbanja kreativnog rešavanja problema, Andragoške studije, Vol. 2016/1. 67-89; Maksić, S. i Đurišić-Bojanović, M. (2004) Kreativnost, znanje i školski uspeh, Zbornik instituta za pedagoška istraživanja, Vol. 36, str. 85-105. 
и наставника-неуметника за остваривање циљева, задатака, садржаја и образовних исхода наставног предмета ликовна култура и на квалитет васпитно-образовног процеса.

Постављене хипотезе истраживања у глобалу имају научно утемељење у досадашњем искуству васпитача и ликовних педагога, као и налазима других аутора, али такође и отварају низ питања о узрочно-последичним везама и деловању праћеног фактора која су отворена и донекле и откривена овим истраживањем.

\section{Варијабле}

Као независна варијабла у овом истраживању јавља се: иницијално образовање наставника-уметника (наставника ликовне културе) и наставника-неуметника (учитеља или професора разредне наставе), односно два различита вида професионалне припреме ${ }^{10}$. У првом случају наставника разредне наставе или учитеља, а у другом наставника или професора за предмет Ликовна култура. Зависне варијабле у овом истраживању јављају се кроз резултате које су наставници ликовне културе и учитељи постигли у оквиру овог истраживања, односно стручне компетенције, а то су: 1. ликовни језик и степен коришћења у одговору на визуелни задатак који се сагледава кроз компоненте ликовно-обликовних аспеката као што су: ликовна поетика, идејна порука/ комуникативност рада, симболика рада, експресивност израза и иконографија; 2. креативност по компонентама: продуктивност, флуентност, оригиналност, положај иртежа (асиметрија-симетрија) и елаборащчија (вербални коментар).

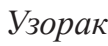

Укупан број испитаника који чине узорак износи тристотинетридесетдва (332) наставника-уметника (наставника ликовне културе) и наставника-неуметника (професора разредне наставе). Тестирањем су били обухваћени наставници и учитељи из тринаест (13) градова у Србији и то: Београд, Нови Сад, Ниш, Крушевац, Лесковац, Пирот, Шабац, Панчево, Ариље, Крупањ, Љубовија, Смедерево и Прокупље.

10 Треба напоменути да су у овом истраживању само условно учитељи названи „неуметници”, а наставници предмета Ликовна култура „уметници”. Тачније речено, сасвим је извесно да и међу учитељима има оних који су наклоњени уметности, односно поседују извесне кометенције или потенцијале за стваралачку (креативну) продукцију. Детерминисање ових појмова је ослоњено примарно на стручне компетенције спречене формалним образовањем. 
Тестирање испитаника је обављено у основним школама у периоду од јануара 2014. до јуна 2017. године у посебно организованим условима где је одређено једнако време, технички услови, материјали и инструкције за реализацију ликовних задатака/цртежа. Узорак је обухватио: 166 наставника-неуметника (учитеља или професора разредне наставе) и 166 наставника-уметника, односно наставника ликовне културе. Подаци који су прикупљени о испитаницима подразумевали су: пол; узраст; иницијално образовање; васпитно-образовна установа у којој је запослен.

Критеријуми истраживања дефинисани су кроз конкретне нормативе, како би се са њима постигла интерсубјективна сагласност између процењивача (психолог, андрагог, ликовни уметник/методичар) у оквиру дефиниције сваког од показатеља. У истраживању је примењен „Еx-post facto” поступак.

\section{Инструменти}

Карактеристике креативног, дивергентног мишљења праћене су на основу показатеља преузетих из стандардизованог, вишедимензионалног истраживачког инструмента под називом: Модификовани креативни тест Вилијамса. ${ }^{11}$ Елена Туник је током трогодишњег истраживачког рада прилагодила тест и дала одговарајуће норме. За потребе овог истраживања тест је ограничен на два задатка организована у пет субскала: продуктивност, флуентност, оригиналност, положај иртежа (асиметрија-симетрија) и елаборација (богатство речника, односно вербални коментар). Укупан скор испитаника се добија сабирањем скорова за свих пет субскала. На основу разлика које се јављају у погледу карактеристика ликовног израза, зависно од иницијалног образовања у области ликовне уметности, односно ликовне педагогије, праћене су њихове карактеристике кроз компоненте креативности и довођене су у везу са иницијалним образовањем као фактором који утиче на компетенције наставника и васпитача у области наставе ликовне културе. По дефиницији Е. Е. Туник, при обради експерименталних података обучени процењивачи су се ослањали на следеће норме:

1. Продуктивност - независно од садржаја цртежа броји се сваки нацртани цртеж. Теоријска претпоставка је да креативне личности продукују више.

2. Флуентност - сагледава се број промена садржаја цртежа, односно мењање категорија. Креативне личности чешће

11 Туник Е. Е. (2003) Модифицированные креативные тесть Вильямса, Санкт-Петербург: Речь. 
мењају по нешто, него што се држе устаљених процедура, путева, или једног типа категорије цртежа. Мишљење је флексибилно. Испитаник је у стању да производи различите идеје, мења своју позицију, на нов начин посматра познате ствари.

3. Оригиналност - процењује се кроз положај нацртаног цртежа у односу на задати стимулус - линију или цртеж унутра или споља у односу на задати цртеж или линију. У сваком квадрату је задата линија или фигура која представља или постаје ограничење за мање креативне особе. Најоригиналнији су они који цртају унутар и споља задате фигуре стварајући смислену синтезу датих облика и које не омета, ограничава дата контура.

4. Асиметрија-симетрија (положај цртежа) - указује на положај детаља на цртежу, да ли га одређују као симетричан или асиметричан. Асиметрични избори су вредновани као израз креативности.

5. Елаборација (наслов) - представља богатство речника и речи које су коришћене у називима, способност сликовитог изражавања суштине цртежа, директан опис онога што се налази на цртежу или откривање скривеног смисла, подтекста.

Критеријуми за анализу ликовног језика креирани кроз вишедимензионални инструмент Ликовно-обликовних аспеката цртежа, посебно креираног за потребе овог истраживања, а који се ослања на основне елементе ликовног језика и комуникације (наратив и ,адресирана” ликовна порука), као и на Tест седам цртежа. ${ }^{12}$ Укупан скор испитаника се добија сабирањем скорова за четири субскале и то: ликовна поетика, идејна порука, симболика рада и експресивност израза, док су се унутар субскала ликовна поетика, симболика рада одређени аспекти пратили квалитативном анализом, укључујући и иконографију. Инструмент се састоји од следећих норматива:

1. Ликовна поетика - представља стил приказа мотива и идеје, ликовни језик и сагледава се кроз начин на који аутор преноси идеју и постиже стилско јединство у раду. Визуелни садржај може бити представљен различито, кроз мuмезис (рад по природи, аналитички, студиозно са извесним оригиналним акцентовањем или буквално подражавање); стилизацију (поступак елиминације сувишних детаља зарад чистоте израза, свођење на једноставне елементе, на

12 Karlavaris, B. i Kraguljac, M. (1970) Test sedam crteža, Novi Sad: Centar za likovno vaspitanje dece i omladine Vojvodine. 
симбол, знак, емоционална непропорционалност, карикатуралност...) и апстракцију (нефигурални визуелни прикази који немају материјалне повезаности са реалним изгледом мотива).

2. Идејна порука - подразумева комуникативност/побуђеност, односно повезаност визуелног садржаја са идејном поруком, њеним контекстом, значењем који се шаље ,адресанту" на инвентиван начин (проналазачки дух, досетљивост, духовитост).

3. Симболика рада - семиотички аспект рада који се сагледава кроз симболику наратива, начин приказа идеје кроз визуелну метафорику (заједничка одлика различитих бића, предмета заснована на сличности или асоцијацијама са одређеним појавама), алегорију (представљање апстрактних појмова у пренесеном значењу помоћу неке фигуре, композиције или помоћу персонификације) и персонификацију (визуелни приказ апстрактних појмова, неживих предмета којима се приписују особине живих бића) или одсуство семиотичког аспекта (буквалан приказ, нема виши/дубљи ниво значења, контекста ликовног рада).

4. Експресивност - сагледава се кроз, ликовно-изражајна средства, емоционалан однос целине и делова цртежа, односно снагу израза и начин грађења визуелне структуре ликовним елементима.

5. Иконографија (представља карактер визуелног садржаја, приказ мотива и тема ликовним средствима) по категоријама:

Приказ човека (портрет, групни аутопортрет, групни портрет, акт) - Приказ људског лика или фигуре који је интиман (са израженим индивидуалним и емоционалним особеностима кроз карактеризацију лика) или репрезентативан (више формалан, са тежиштем на истицању друштвеног значаја или положаја личности - историјске, религијске, популарне...).

- Жанр-сиена (свакодневица, дружење, удруживање, игра, прослава, уметност, спорт, ритуали.....; историјски догађаји) - Приказ свакодневног живота људи из различитих друштвених слојева кроз процесе рада или односе.

- Мртва природа - Приказ аранжираних предмета и неживих облика из природе у неком ентеријеру.

- Пејзаж (урбани, рурални, природни) - Мотив који приказује природу и њене пределе или ведуте као и 
природне појаве и непогоде (насељена места - сеоска или градска).

- Декоративни мотиви (геометријски, зооморфни, апстрактни, антропоморфни).

- Жива бића (биљке - декоративне собне, дивље из природе...; животиње - сисари; зглавкари - ракови, пауци, шкорпије, инсекти, стоноге...; рибе; птице; микросвет; бодљокошци - јежеви, звезде...; мекушци - шкољке, пужеви; гмизавци - змија, корњача, крокодил..; водоземци - жаба, тритон, даждевњак...; глисте...).

- Машта и веровања (фантастични ликови и бића који су производ маште ствараоца; митологија; бајке и народна предања; религије различитих народа) - Приказ неког необичног, мистичног, бајковитог амбијента у коме се фантастична бића могу појавити у контексту који није повезан са реалношћу, на нов и неуобичајен начин.

- Емоције и апстрактни појмови (правда, срећа, несрећа, туга, мисао, љубав, звук, креатање....)

- Предмети које је креирао/произвео човек.

Статистичке методе

У обради података, до којих се дошло истраживањем, доминирали су непараметријски статистички поступци. Било је предвиђено да се израчунавају мерне вредности добијене процењивањем, које су у што већој мери биле објективизиране, захваљујући јасно дефинисаним категоријама и уз учешће квалификованих процењивача. Добијени подаци (изражени бројевима) су организовани тако да дају прегледну и лако разумљиву слику добијених резултата. У обради квалитативних података резултата истраживања добијених инструментом за анализу ликовно-обликовних аспекта цртежа и тестирања хипотезе, коришћен је процентни рачун и Xи-квадрат тест. Резултати до којих се дошло, омогућили су да се утврди колика је повезаност међу укрштеним карактеристикама. Израчунати су дескриптивни параметри мере централне тенденције и мере одступања. За тестирање хипотезе коришћен је Студентов $T$ - тест за значајност разлике аритметичких средина.

\section{Резултати истраживања}

Резултати за креативност наставника - уметника (наставника предметне наставе) и наставника - неуметника (наставника разредене наставе) на Вилијамс тесту 
У Табели 1 приказане су ариметичке средине и стандардне девијације, у Табели 2 значајност разлике за сваку субскалу, као и за укупан скор Вилијамс теста креативности за наставнике -уметнике и наставнике-неуметнике.

Наставници - уметници се од наставника - неуметника разликују у погледу креативности сагледаване вишедимензионалним тестом креативности Вилијамс. Израчуната вредност значајности разлике аритметичких средина укупних резултата наставника-уметника и наставника-неуметника је на нивоу $\alpha .001$ већа од табличне $[\mathrm{t}(330)=26.66, \mathrm{p}<.001]$ у корист наставника-уметника, односно наставника ликовне културе. Ипак, када се постигнуће ове две групе пореди на свакој од субскала појединачно, уочава се да за Продуктивност нема разлике између ове две групе испитаника $[\mathrm{t}(330)=0.579$, $\mathrm{p}<.03]$, док на скалама Флуентност $[\mathrm{t}(330)=3.278, \mathrm{p}<.001]$, Оригиналност $[\mathrm{t}(330)=31.923 \mathrm{p}<.001]$, Асиметрија-симетрија $[\mathrm{t}(330)=24.827, \mathrm{p}<.001]$ и Елаборащија $[\mathrm{t}(330)=8.243$, $\mathrm{p}<.001]$ наставници - уметници постижу боље резултате.

\begin{tabular}{l|l|l|l|l}
\hline Вилијамс тест креативности & \multicolumn{2}{|l|}{ наставници-уметници } & \multicolumn{2}{l}{ наставници-неуметници } \\
\hline Дескриптивне мере & $\mathrm{M}$ & $\mathrm{SD}$ & $\mathrm{M}$ & $\mathrm{SD}$ \\
\hline Креативност (укупни скор) & 17.531 & 3.353 & 9.421 & 2.024 \\
Продуктивност & 1.993 & 0.077 & 1.987 & 0.109 \\
Флексибилност & 1.969 & 0.170 & 1.855 & 0.414 \\
Оригиналност & 5.307 & 1.062 & 2.253 & 0.617 \\
Асиметрија-симетрија & 4.150 & 1.699 & 0.536 & 0.781 \\
Елаборација & 4.102 & 1.604 & 2.771 & 1.30 \\
\hline
\end{tabular}

Напомена: N - број испитаника; M - аритметичка средина; SD - стандардна девијација

Табела 1 Дескриптивне мере креативности код наставникауметника и наставника-неуметника

Варијабле: наставници-уметници (N 166) и наставници-неуметници (N 166)

\begin{tabular}{llll}
\hline Студентов Т-тест значајности разлике (df 330) & $t$ & $t v$ & $p$ \\
\hline Креативност (укупни скор) & 26.66 & 3.29 & $<.001$ \\
\hline Продуктивност & 0.579 & 0.52 & $<.30$ \\
\hline Флексибилност & 3.27 & 2.32 & $<.01$ \\
\hline Оригиналност & 31.92 & 3.29 & $<.001$ \\
\hline Асиметрија-симетрија & 24.82 & 3.29 & $<.001$ \\
\hline Елаборација & 8.243 & 3.29 & $<.001$ \\
\hline
\end{tabular}

Напомена: $\mathrm{N}$ - број испитаника; $t$ - Студентов Т-тест значајности разлике; $\mathrm{df}$ - степен слободе; $t v$-табличне вредности степена слободе; $p$ - ниво статистичке значајности

Табела 2 Значајност разлике креативности код наставникауметника и наставника-неуметника 


\section{Резултати ликовно-обликовних аспеката} цртежа наставника-уметника (наставника ликовне културе) и наставника-неуметника (наставника разредене наставе)

У Табели 3 приказане су аритметичке средине и стандардне девијације ликовно-обликовних аспектата цртежа, у Табели 4 значајност разлике за сваку субскалу, као и за укупан скор ликовно-обликовних аспеката за наставнике уметнике и наставнике-неуметнике.

\begin{tabular}{l|l|l|l|l}
\hline Ликовно-обликовни аспекти иртежа & \multicolumn{2}{|l|}{$\begin{array}{l}\text { наставници- } \\
\text { уметници }\end{array}$} & \multicolumn{2}{l}{$\begin{array}{l}\text { наставници- } \\
\text { неуметници }\end{array}$} \\
\hline Дескриптивне мере & M & SD & M & SD \\
\hline Ликовно-обликовни аспекти (укупан & 31.19 & 6.567 & 9.006 & 5.908 \\
скор) & & & & \\
Ликовна поетика & 8.668 & 1.864 & 1.927 & 1.883 \\
Идејна порука/комуникативност рада & 5.445 & 0.924 & 2.518 & 1.429 \\
Симболика рада & 8.349 & 2.543 & 1.765 & 1.782 \\
Експресивност израза & 8.723 & 1.844 & 2.791 & 2.021 \\
\hline
\end{tabular}

Напомена: $\mathrm{N}$ - број испитаника; M - аритметичка средина; SD - стандардна девијација

Табела 3 Дескриптивне мере ликовно-обликовних аспеката цртежа код наставника-уметника и наставника-неуметника

\begin{tabular}{l|l|l|l|l}
\hline Ликовно-обликовни аспекти иртежа & \multicolumn{2}{|l|}{\begin{tabular}{l}
\multicolumn{2}{|l}{ наставници- } \\
уметници
\end{tabular}} & \multicolumn{2}{|l}{\begin{tabular}{l}
\multicolumn{2}{|l}{ наставници- } \\
Лесници
\end{tabular}} \\
\hline Дескиптивне мере & $\mathrm{M}$ & $\mathrm{SD}$ & $\mathrm{M}$ & $\mathrm{SD}$ \\
\hline Ликовно-обликовни аспекти (укупан & 31.19 & 6.567 & 9.006 & 5.908 \\
скор) & & & & \\
Ликовна поетика & 8.668 & 1.864 & 1.927 & 1.883 \\
Идејна порука/комуникативност рада & 5.445 & 0.924 & 2.518 & 1.429 \\
Симболика рада & 8.349 & 2.543 & 1.765 & 1.782 \\
Експресивност израза & 8.723 & 1.844 & 2.791 & 2.021 \\
\hline
\end{tabular}

Напомена: N - број испитаника; M - аритметичка средина; SD - стандардна девијација

Табела 4 Значајност разлике ликовно-обликовних аспеката цртежа код наставника-уметника и наставника-неуметника

Наставници - уметници се од наставника - неуметника разликују у погледу ликовног језика сагледаване вишедимензионалним инструментом Ликовно-обликовних аспеката цртежа. Израчуната вредност значајности разлике аритметичких средина укупних резултата наставника-уметника и наставника-неуметника је на нивоу $\alpha .001$ већа од табличне $[\mathrm{t}(330)=32.35, \mathrm{p}<.001]$ у корист наставника-уметника, односно наставника ликовне културе. Када се постигнућа ове две групе пореди на свакој од субскала појединачно, уочава се да има разлике између ове две групе испитаника и то за Ликовну поетику $[\mathrm{t}(330)=32.77, \mathrm{p}<.001]$, за Идејну 
поруку $[\mathrm{t}(330)=22.15, \mathrm{p}<.001]$, за Симболику рада $[\mathrm{t}(330)=$ $27.32, \mathrm{p}<.001]$, као и за Експресивност израза $[\mathrm{t}(330)=27.95$, $\mathrm{p}<.001]$, при чему наставници - уметници постижу боље резултате за сваку од субскала.

\section{Хи-квадрат тест и коефицијент контингенције} за резултате ликовне поетике, симболике рада и иконографију у иртежима наставника -

уметника и наставника - неуметника

У Табели 5 приказана је процентна заступљеност аспеката Ликовне поетике, у Табели 6 Симболике рада, а у Табели 7 Иконографије у цртежима наставника - уметника и цртежима наставника - неуметника. У Табели 8 приказани су резултати Хи-квадрат теста и коефицијент контингенције за Ликовну поетику, Симболику рада и Иконографију у цртежима наставника - уметника и цртежима наставника неуметника.

\begin{tabular}{lllll}
\hline Ликовна поетика & наставници-уметници & наставници-неуметници \\
\hline Миметички приступ & 58 & $17.46 \%$ & 276 & $83.1 \%$ \\
Стилизација & 208 & $62.65 \%$ & 53 & $15.9 \%$ \\
Апстракција & 66 & $19.87 \%$ & 3 & $1.0 \%$ \\
\hline Број цртежа & 332 & & 332 & \\
\hline
\end{tabular}

Табела 5 Процентна заступљеност аспеката ликовне поетике у цртежима наставника - уметника и цртежима наставника неуметника

У резултатима цртежа који се односе на Ликовну поетику, или ликовни израз представља стил приказа мотива и идеje, и сагледава се кроз начин на који аутор преноси идеју и постиже стилско јединство у раду, праћено је колика је учесталост миметичког приступа (рад по природи, аналитички, студиозно са извесним оригиналним акцентовањем или буквално подражавање); стилизачије (поступак елиминације сувишних детаља зарад чистоте израза, свођење на једноставне елементе, на симбол, знак, емоционална непропорционалност, карикатуралност...) и апстракције (нефигурални визуелни прикази који немају материјалне повезаности са реалним изгледом мотива) у цртежима наставника уметника и наставника - неуметника. Реализовано је укупно 664 цртежа. Сваки наставник је реализовао по два цртежа и то 166 наставника предметне наставе и 166 цртежа наставника разредне наставе.

Миметички приступ (рад по природи, аналитички, студиозно са извесним оригиналним акцентовањем или буквално подражавање) је заступљен у 58 цртежа наставника - уметника или $17.46 \%$, док је мимезис идентификован код 276 
цртежа наставника - неуметника, односно $83.13 \%$ цртежа, од укупне популације испитаника за овај део узорка.

Стилизащија (поступак елиминације сувишних детаља зарад чистоте израза, свођење на једноставне елементе, на симбол, знак, емоционална непропорционалност, карикатуралност...) је заступљена у 208 цртежа наставника - уметника или $62.65 \%$, док се код наставника - неуметника, стилизација појављује у 53 цртежа, односно $15.97 \%$ од укупне популације испитаника за овај део узорка.

Anстракција (нефигурални визуелни прикази који немају материјалне повезаности са реалним изгледом мотива) је заступљена у 66 цртежа наставника - уметника или 19.87\%, док се код наставника - неуметника, апстракција појављује у само 3 цртежа, односно $0.9 \%$ од укупне популације испитаника за овај део узорка.

\begin{tabular}{lllll}
\hline Симболика рада & \multicolumn{2}{l}{ наставници-уметници } & \multicolumn{2}{l}{ наставници-неуметници } \\
\hline Визуелна метафорика & 116 & $34.93 \%$ & 61 & $18.37 \%$ \\
Алегорија & 94 & $28.31 \%$ & 35 & $10.55 \%$ \\
Персонификација & 67 & $20.18 \%$ & 9 & $2.71 \%$ \\
Одсуство симболике & 55 & $16.56 \%$ & 227 & $68.37 \%$ \\
\hline Број цртежа & 332 & & 332 & \\
\hline
\end{tabular}

Табела 6 Процентна заступљеност аспеката Симболике рада у цртежима наставника - уметника и цртежима наставника неуметника

У резултатима цртежа који се односе на Симболику рада, односно семиотички аспект цртежа који се сагледава кроз симболику наратива, начин приказа идеје кроз визуелну метафорику (заједничка одлика различитих бића, предмета заснована на сличности или асоцијацијама са одређеним појавама), алегорију (представљање апстрактних појмова у пренесеном значењу помоћу неке фигуре, копозиције или помоћу персонификације), персонификащију (визуелни приказ апстрактних појмова, неживих предмета којима се приписују особине живих бића), као и одсуство симболике, семиотичког аспекта (буквалан приказ, нема виши/дубљи ниво значења, контекста ликовног рада). Реализовано је укупно 664 цртежа. Сваки наставник је реализовао по два цртежа и то 166 наставника предметне наставе и 166 цртежа наставника разредне наставе.

Визуелна метафорика (различитих бића, предмета заснована на сличности или асоцијацијама са одређеним појавама) је заступљена у 116 цртежа наставника - уметника или $34.93 \%$, док се код наставника - неуметника појављује у 61 цртежу, односно $18.37 \%$, од укупне популације испитаника за овај део узорка. 
Алегорија (представљање апстрактних појмова у пренесеном значењу помоћу неке фигуре, копозиције или помоћу персонификације) је заступљена у 94 цртежа наставника уметника или $28.31 \%$, док се код наставника - неуметника, алегорија појављује у 35 цртежа, односно $10.55 \%$ од укупне популације испитаника за овај део узорка.

Персонификација (визуелни приказ апстрактних појмова, неживих предмета којима се приписују особине живих бића) је заступљена у 67 цртежа наставника - уметника или $20.18 \%$, док се код наставника - неуметника, персонификација појављује у само 9 цртежа, односно $2.71 \%$ од укупне популације испитаника за овај део узорка.

Одсуство симболике, семиотичког аспекта у иртежу (буквалан приказ, нема виши/дубљи ниво значења, контекста) идентификовано је код наставника - уметника у 55 цртежа, што износи $16.56 \%$ од укупног узорка овог дела популациje, док је код наставника - неуметника одсуство симболике рада идентификовано чак у 227 цртежа, односно 68.37\% од укупне популације испитаника за овај део узорка.

\begin{tabular}{|c|c|c|c|c|c|c|}
\hline \multirow{2}{*}{$\begin{array}{l}\text { Иконографија } \\
\text { Приказ човека }\end{array}$} & \multicolumn{2}{|c|}{$\begin{array}{l}\text { наставници- } \\
\text { уметници }\end{array}$} & \multicolumn{2}{|c|}{$\begin{array}{l}\text { наставници- } \\
\text { неуметници }\end{array}$} & \multicolumn{2}{|l|}{$\sum$} \\
\hline & 94 & $28.31 \%$ & 107 & $32.2 \%$ & 201 & $30.27 \%$ \\
\hline Жанр-сцена & 6 & $1.8 \%$ & 0 & $0 \%$ & 6 & $0.9 \%$ \\
\hline Мртва природа & 3 & $0.9 \%$ & 4 & $1.2 \%$ & 7 & $1.05 \%$ \\
\hline Пејзаж & 57 & $17.16 \%$ & 70 & $21.08 \%$ & 127 & $19.12 \%$ \\
\hline Декоративни мотиви & 22 & $6.62 \%$ & 43 & $12.95 \%$ & 65 & $9.78 \%$ \\
\hline Жива бића & 61 & $18.37 \%$ & 64 & $19.27 \%$ & 125 & $18.82 \%$ \\
\hline Машта и веровања & 35 & $10.54 \%$ & 3 & $0.9 \%$ & 38 & $5.72 \%$ \\
\hline Емоције и апстрактни појмови & 41 & $12.34 \%$ & 7 & $2.1 \%$ & 47 & $7.07 \%$ \\
\hline $\begin{array}{l}\text { Предмети које је креирао } \\
\text { човек }\end{array}$ & 13 & $3.91 \%$ & 34 & $10.24 \%$ & 47 & $7.07 \%$ \\
\hline Број цртежа & 332 & & 332 & & 664 & \\
\hline
\end{tabular}

Табела 7 Процентна заступљеност мотива по категоријама Иконографије у цртежима наставника - уметника и цртежима наставника - неуметника

У резултатима цртежа који се односе на Иконографију, односно карактер визуелног садржаја, приказа мотива и тема ликовним средствима реализовано је укупно 664 цртежа. Сваки наставник је реализовао по два цртежа и то 166 наставника предметне наставе и 166 цртежа наставника разредне наставе.

Приказ човека - приказ људског лика или фигуре који је интиман (са израженим индивидуалним и емоционалним особеностима кроз карактеризацију лика) или репрезентативан (више формалан, са тежиштем на истицању друштвеног значаја или положаја личности - историјске, религијске, популарне...) је заступљен у 94 цртежа наставника - 
уметника или $28.31 \%$, док се код наставника - неуметника појављује у 107 цртежа, односно 32.22\%, од укупне популације испитаника за овај део узорка.

Жанр-сцена - приказ свакодневног живота људи из различитих друштвених слојева кроз процесе рада или односе је заступљена у 6 цртежа наставника - уметника или $1.8 \%$, док је код наставника-неуметника није идентификован овај мотив.

Мртва природа - приказ аранжираних предмета и неживих облика из природе у неком ентеријеру, идентификована је као мотив на 3 цртежа наставника - уметника односно $0.9 \%$, док се код наставника - неуметника појављује у 4 цртежа, односно $1.2 \%$, од укупне популације испитаника за овај део узорка.

Пејзаж - мотив који приказује природу и њене пределе или ведуте као и природне појаве и непогоде (насељена места сеоска или градска) заступљен је у чак 57 цртежа наставника - уметника или $17.16 \%$, док се код наставника - неуметника појављује у чак 70 цртежа, односно $21.08 \%$, од укупне популације испитаника за овај део узорка.

Декоративни мотиви - обрађени су у 22 цртежа наставника - уметника или $6.62 \%$, док се код наставника - неуметника заступљени су на 43 цртежа, односно 12.95\%, од укупне популације испитаника за овај део узорка;

Жива бића - као мотив се појављују у 61 цртежу наставника - уметника или $18.37 \%$, док се код наставника - неуметника појављују се у 64 цртежа, односно 19.27\%, од укупне популације испитаника за овај део узорка.

Машта и веровања - приказ неког необичног, мистичног, бајковитог амбијента у коме се фантастична бића могу појавити у контексту који није повезан са реалношћу, на нов и неуобичајен начин, идентификовани су у 35 цртежа наставника - уметника или $10.54 \%$, док се код наставника - неуметника појављује се само у 3 цртежа, односно $0.9 \%$, од укупне популације испитаника за овај део узорка.

Емоџије и апстрактни појмови - идентификовани су код 40 цртежа наставника - уметника или $12.34 \%$, док се код наставника - неуметника појављују се као мотив на 7 цртежа, односно 2.1\%, од укупне популације испитаника за овај део узорка.

Предмети које је креирао/произвео човек - као мотив се појављују у 13 цртежа наставника - уметника или $3.91 \%$, док се код наставника - неуметника појављује у 34 цртежа 
или $10.24 \%$, од укупне популације испитаника за овај део узорка.

\begin{tabular}{lllll}
\hline Наставници-уметници (N 332 цртежа) и наставници-неуметници (N 332 цртежа) \\
Хи-квадрат и коефицијент контингенције (df2) & $\chi 2$ & tv & $p$ & C \\
\hline Ликовна поетика & 291.85 & 13.815 & $<.001$ & 0.552 \\
Симболика рада & 193.24 & 13.815 & $<.001$ & 0.472 \\
Иконографија & 72.026 & 13.815 & $<.001$ & 0.312 \\
\hline Напомена: $\mathrm{N}$ - број цртежа по третману; C - коефицијент контингенције, с степен \\
повезаности две варијабле; $\chi 2$ - Хи-квадрат тест значајности разлике; df - степен слободе; \\
tv - таблична вредност степена слободе; $p$ - ниво статистичке значајности)
\end{tabular}

Табела 8 Хи-квадрат тест и коефицијент контингенције за Ликовну поетику, Симболику рада и Иконографију у цртежима наставника - уметника и цртежима наставника - неуметника

Будући да је израчуната вредност Хи-квадрат статистике већа од граничне вредности и то за Ликовну поетику $[\chi 2(664)=291.85,<.001]$, Симболику рада $[\chi 2(664)=193.24$,

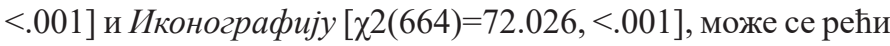
да постоји статистички значајна разлика између теоријских фреквенција за ова два узорка.

\section{Дискусија о резултатима}

Полазећи од резултата бројних истраживања у коме су идентификоване разлике у погледу опште креативности између уметника и неуметника, спроведено је слично и истраживање и код нас, ${ }^{13}$ где је испитивана разлика између уметника и неуметника (популација студента) у погледу опште креативне способности и различитих аспеката креативности, помоћу вишедимензионалног теста опште креативности (базиран на Гилфордовом моделу креативног мишљења). Овај тест, како наводе истраживачи, процењује општу креативну способност и четири аспекта креативности нижег реда: флуентност, продуктивност, оригиналност и елаборацију. Резултати истраживања су показали разлике између уметника и неуметника, у прилог уметника, који имају боља постигнућа на субскали Оригиналност, док између ове две групе испитаника нема разлике на субскали Продуктивност. „Добијени резултати сугеришу постојање опште креативне способности која није резервисана само за уметнике. Ипак, разлике у постигнућу у домену оригиналности упућују на постојање доминантног начина креативног мишљења у групи уметника."14

13 Erić, M., Bjekić, J., Stojimirović, E. i Živanović, M. (2012) Opšta kreativna sposobnost i aspekti kreativnog mišljenja kod umetnika i neumetnika, Primenjena psihologija, Vol. 5 (2) str. 169-182.

14 Исто, стр. 176. 
Аутори сличних истраживања се позивају на став о креативности као јединственој способности која разликује уметнике од неуметника говоре углавном истраживања која се баве креативношћу особе, а не њеног уметничког продукта. У прилог томе говоре и резултати психометријских истраживања, у којима су коришћени тестови креативних способности који по форми личе на тестове интелигенције, а који показују да је креативност јединствен конструкт различит од интелигенције и конструката личности. ${ }^{15}$ „Ако претпоставимо да је смисао визуелног доминантан у западној култури, од великог је значаја како сугеришу у свом чланку Поглед на концепт визуелне писмености, способност да се комуницира посредством цртежа, што аутоматски укључује и способност да се црта."

Цртање је, према Виготском концептуализовање симбола; представљање у пренесеном значењу, као „конфигурациони" знак на папиру ${ }^{17}$ који симболизује стварне предмете, појаве или феномене које би требало изразити кроз цртеж. То je оно што Виготски карактерише као стварање и употреба „система другог реда” или „имплицитни ред”, што нас, према Виготском, издваја као људе. ${ }^{18}$

У овом истраживању пошло се од задатка да се утврди да ли постоје разлике у креативности и ликовно-обликовним аспектима цртежа као основа ликовне писмености код наставника - уметника (наставника ликовне културе) и наставника - неуметника (наставника разредне наставе), а у зависности од врсте иницијалног образовања за професију наставника.

Резултати овог истраживања су показали су следеће:

Статистички значајне разлике аритметичких средина укупних резултата наставника - уметника и наставника неуметника на Вилијамс тесту креативности и резултата по субскалама Флуентност, Оригиналност, Симетри-

\footnotetext{
15 Исто, стр. 171
}

16 Scott, F. N. (2010) To see the visually controlled: Seeing-drawing in formal and informal contexts, Trondheim: Norwegian University of Science and Technology Faculty of Social Sciences and Technology Management Department of Education, p. 247.

17 Wilson, B. and Wilson, M. (1977) An iconoclastic view of the imagery sources in the drawing of oung people, Art Education, 1, pp. 5-11.

18 Scott, F. N. (2010) To see the visually controlled: Seeing-drawing in formal and informal contexts, Trondheim: Norwegian University of Science and Technology Faculty of Social Sciences and Technology Management Department of Education, p. 247. 
ја-асиметрија (положај цртежа) и Елаборащија (вербални коментар), а у корист резултата наставника - уметника.

Није уочена статистички значајна разлика за субскалу Продуктивност.

Статистички значајне разлике аритметичких средина укупних резултата наставника - уметника и наставника - неуметника за Ликовно-обликовне аспекте иртежа и резултата по субскалама Ликовна поетика, Идејна порука, Симболика рада и Експресивност израза, при чему наставници уметници постижу боље резултате за сваку од субскала.

У квалитативној анализи унутар критеријума Ликовна поетика, Симболика рада и Иконографија идентификована је статистички значајна разлика између теоријских фреквенција за ова два узорка.

Драстичне разлике између аритметичких средина на укупним резултатима Ликовно-обликовних аспеката иртежа, као и праћеним субскалама између ова два узорка, само делимично би могле да се тумаче селекцијом при упису на матичне факултете (уметнички или учитељски), пошто се ликовна поетика изграђује током читавог школовања у области теорије ликовних уметности и ликовно-уметничке праксе.

Такође, резултати показују да су наставници - неуметници (наставници разредне наставе) те компетенције применили у веома малом степену у тестом задатим цртежима. Највише забрињава слика која нам указује да код наставника - неуметника изостаје кључни квалитет стваралачког израза, а то је преношење поруке посредством ликовних медија, односно повезаност визуелног садржаја са идејном поруком, њеним контекстом, значењем који се шаље „адресанту” на инвентиван начин (проналазачки дух, досетљивост, духовитост). У одређеном броју радова наставника - неуметника доминира неповезаност идејне поруке у вербалном и визуелном изразу, а ако идејна порука и постоји, она је често исказана кроз просту визуелну и појмовну репрезентацију („буквалан приказ мотива и поруке”). Код наставника уметника је превагнуо је резултат који иде у прилог заступљености повезаности и „комуникативности” идејне поруке, контекста, значења и визуелног приказа/визуелизације кроз карактеризацију делова или целине; изражајност визуелних порука и симбола, духовитост, маштовитост и сликовити визуелни приказ; метафоричност; јединство форме и наратива и инвенција.

Идентификоване су изражене разлике и код критеријума Експресивност израза, где је код великог броја наставника - 
неуметника идентификовано потпуно одуство експресивности израза, или ако постоји, елементи цртежа су често дезинтегрисани, неповезани, без композиционе организације, и није постигнуто стилско јединство у изразу.

За разлику од наставника - неуметника, када се говори о Експресивности израза, цртеж је често снажан и изражајан, постигнуто је стилско јединство композиције било да је слободно, спонтано компоновање или аналитички приступ организацији елемената цртежа. На пример, заступљени су принципи као што су: репетиција; хармонија; доминанта, контраст облика, светлина, величина; ритам, кретање, динамизам; орнаментални, фрактални системи; правац и смер у композицији...) док су ликовни елементи у функцији цртежа и приказани на маштовит начин (на пример, линије су геометријске „еуклидске” или калиграфске, живописне, структурне или контурне...; приказана је текстура кроз груписање или распршеност елемената цртежа или шрафуру...; приказ облика као 2Д или 3Д, органски или геометријски...; приказ дубине простора и др.).

Разлике које су идентификоване код Ликовне поетике у квалитативној анализи су веома индикативне. Иако већина наставника - уметника употребљава стилизацију у цртежу, миметички приступ и апстракција се приближно употребљаваjу, при чему је већина цртежа аутентична, са оригиналном ликовном поетиком и јединством израза и метода, без обзира да ли је цртеж апстрактан, стилизован или миметички.

У цртежима наставника - неуметника је идентификован један дисхармоничан однос, при чему мимезис, или рад по природи доминира. Он што је забрињавајуће јесте да је у великом броју цртежа наставника - неуметника присутан шаблонизам - стереотип у раду, шематски натурализам, копирање, кич, преузимање готових облика и модела у изражавању, одсуство аутентичности, или, ако нема присуства шаблонизма, израз је често несигуран и неаутентичан, недоследан у идеји и методу.

Од свих идентификованих разлика, најупадљивије су за критеријум Ancтракичја, где је само 1.0\% цртежа наставника - неуметника насупрот 66\% цртежа наставника - уметника који су се изразили кроз апстрактан цртеж.

Ови резултати у великој мери одступају од захтева Cmaндарда компетенција за професију наставника у оквиру све четири категорије (К1, К2, К3, К4) које се подразумевају да их је наставник стекао у оквиру иницијалног образовања. За ово истраживање посебно значајне компетенције К1 - Компетенције за наставну област, предмет и методику наставе 
и К2 - Компетенције за поучавање и учење, у којима се, поред осталих компетенција подразумева да наставник:

- Зна научну/уметничку дисциплину којој припада предмет који предаје и њене везе са другим дисциплинама;

- Разуме социјалну релевантност садржаја предмета;

- Остварује функционалне, образовне и васпитне циљеве у складу са општим принципима, циљевима и исходима образовања, наставним планом и програмом предмета који предаје, прилагођавајући их индивидуалним карактеристикама и могућностима ученика;

- Систематски уводи ученике у научну/уметничку дисциплину;

- Планира подстицање дивергентног мишљења код ученика;

- Планира активности којима се развијају научни/ уметнички појмови код ученика;

- Планира различите активности којима подстиче креативност код ученика. ${ }^{19}$

Треба још напоменути да су у званичним програмима за наставу ликовне културе у основној школи од 1. до 8. разреда, поред теорије форме, ликовних техника и материјала, практичних ликовних активности, предвиђени су и садржаји светске и националне културне баштине и праисторијску, старовековну, средњевековну, нововековну, модерну и савремену уметност.

Поставља се питање: Када имамо овакве резултате личних преференција наставника - неуметника (имплицитна педагогија), да ли они могу, и у којој мери, да утичу на васпитно-образовну праксу и да остварују програмске циљеве, задатке и образовне исходе наставног предмета ликовна култура, посебно када се говори о развијању и подстицању креативности ученика и ликовно-обликовних аспеката дечјег стваралачког изражавања?

Симболички израз је у резултатима наставника - уметника уравнотежен између праћених критеријума. У највећем броју цртежа идентификован је на инвентиван, оригиналан начин коришћења симболичког наратива у пренесеном значењу кроз метафору, алегорију и персонификацију. Ипак, уочен је и известан број оних код којих је доминирао

19 Стандарди компетенција за професију наставника и њиховог професионалног развоја (2011) Београд: ЗУОВ. 
натуралистички приказ идеје/мотива, иако је оваквих радова значајно више код наставника - неуметника.

Најизраженије разлике у Иконографији цртежа идентификоване су код мотива Машта и веровања, као и код мотива Eмоције и Апстрактни појмови, што иде у прилог статистички значајним разликама код Ликовне поетике, где је идентификовано одсуство Anстракиије и доминација $\mathrm{Mu}$ мезиса код наставника - неуметника, са шаблонизираним и стереотипним изразом у цртежима. У прилог ових констатација иде и резултат у коме мотив Људске фигуре доминира код обе групе испитаника, при чему наставници уметници најчешће приказују људску фигуру, односно акт, док је у цртежима наставника - неуметника доминатан приказ људског лика кроз стереотипно и шаблонско решавање започетог цртежа.

Полазећи од резултата да постоје статистички значајне разлике у резултатима наставника-уметника и наставника-неуметника за Креативност и Ликовно-обликовни израз, укључујући и субскале за оба инструмента, потврђују се хипотезе да има статистички значајне разлике у креативности и ликовно-обликовном аспекту цртежа наставника-уметника (наставника ликовне културе) и наставника-неуметника (наставника разредне наставе) у зависности од иницијалног образовања за професију наставника. И све то у корист наставника - уметника чије иницијално образовање у матичној области ликовне уметности значајно утиче на ниво креативности и ниво ликовно-обликовних аспеката цртежа, односно на њихове компетенције у настави ликовне културе.

\section{Закључак}

Овим истраживањем је потврђена теза да наставници - неуметници не примењују у довољној мери и основна знања и компетенције из области ликовне уметности/културе и то кроз више аспеката: ниског скора на тесту креативности, посебно када је реч о компоненти оригиналности, велики проценат одсуства симболике израза, идејне поруке, апстрактног цртежа, као и преовладавање стереотијија и шаблонизма у цртежима. Отворена су питања актуелних педагошких перспектива и консеквенци на дечји развој и подршку креативности ученика основношколског узраста, посебно поимања смисла и значаја стваралачких активности у школским програмима, као и методике ликовног васпитања и образовања у раду са основношколском популацијом деце.

Компетенције наставника су један од кључних фактора који утичу на успешност васпитно-образовног процеса у школи, 
посебно интегралног развоја личности, где креативност заузима значајан образовни исход. Поставља се питање да ли наставници-неуметници поседују адекватне кометенције за реализацију свих васпитно-образовних циљева у настави ликовне културе у складу са Стандардима компетенција за професију наставника, узимајући у обзир добијене резултате на тесту креативности и ликовно-обликовних аспеката? Да ли наставници код којих способност креативног изражавања није досегла ниво компетенција из матичне области ликовне уметности, ниво креативне продукције, естеских критеријума, као и сензитивности за идентификовење и подстицање дечје креативности и стваралачког изражавања могу квалитетно остваривати програм, односно циљеве, односно образовне исходе наставног предмета ликовна култура и обезбедити ученицима максималан развојни учинак?

Такође, запажа се последњих година и известан тренд у акредитацији студијских програма на учитељским факултетима у Србији који претендује да образује будуће предметне наставнике ликовне културе, при чему се неки мастер програми за образовање предметних наставника на овим факултетима већ остварују. Ипак, отвара се питање квалитета оваквих студија који негирају матичност, и које би у неком од истраживања требало преиспитати кроз компаративну анализу са програмима уметничких факултета.

Отвара се и читав низ других питања, а која се односе на истраживање нивоа елементарне ликовне писмености наставника-неуметника, њихове способности естетске анализе продуката дечјег ликвног стваралаштва, разумевања ликовне поетике, експресивности, па све до поимања смисла и функције предмета ликовна култура у дечјем развоју опште-образовног током школовања и отворено питање селекције при упису будућег наставног кадра када се ради о тесту креативности, а што не може бити оправдање код одсуства елементарне ликовне писмености која се стиче током школовања, а које је идентификовано овим истраживањем.

Треба указати и на одређене скривене или паразитске факторе, које нисмо држали под контролом, а који су могли утицати на крајње исходе или резултате нашег истраживања. Највише у смислу тога да резултати које смо добили мерењем нису узроковани само разликама у начину професионалне припреме учитеља и наставника ликовне културе, већ и утицајем бројних других фактора (пол, узраст, социјални статус, неформално образовање, индивидуалне склоности, потенцијали и психо-физичке могућности и друго) што овде нисмо могли, нити намеравали, контролисати. На основу резултата овог истраживања, могуће је дати и извесне 
предлоге за унапређивање наставничких компетенција, посебно код наставника - неуметника и то: подићи ниво опште ликовне културе и знања из области ликовне уметности и свих њених дисциплина; увести више ликовно-уметничке праксе и самосталног креативног рада, као и подстицање свих аспеката креативности и ликовно-обликовних аспеката кроз иницијално образовање за професију наставника; у даљем стручном усавршавању запослених у образовању, увести већи број садржаја стручних семинара који подржавају и развијају све претходно наведене аспекте, укључујући и методику наставе ликовне културе.

\section{ЛИТЕРАТУРА:}

Bojanović, R. i Đurišić-Bojanović, M. (2016) Efekti vežbanja kreativnog rešavanja problema, Andragoške studije, Vol. 2016/1, str. 67-89

Erić, M., Bjekić, J., Stojimirović, E. i Živanović, M. (2012) Opšta kreativna sposobnost $\mathrm{i}$ aspekti kreativnog mišljenja kod umetnika i neumetnika, Primenjena psihologija, 2012, Vol. 5 (2) str. 169-182

Janjević, V., Filipović, S. i Tunik, E. (2013) Uporedna analiza razvoja kreativnog mišljenja predškolaca u Peterburgu i Beogradu, Nova škola, VIII (2), str. 93-102. Bijeljina: Pedagoški fakultet.

Karlavaris, B. i Kraguljac, M. (1970) Test sedam crtě̌a, Novi Sad: Centar za likovno vaspitanje dece i omladine Vojvodine.

Кудрявцев, В. Т., Уразалиева, Г. К. и Кириллов, И. Л. (2005) Личносный рост ребенка в дошколном образовании, Москва:

Макспрес.

Maksić, S. i Đurišić-Bojanović, M. (2004) Kreativnost, znanje i školski uspeh, Zbornik instituta za pedagoška istraživanja, Vol. 36, str. 85-105.

Панић, В. (2005) Психологија и уметност, Београд: Завод за уџбенике и наставна средства.

Стандарди компетенција за професију наставника и юиховог професионалног развој (2011) Београд: ЗУОВ.

Scott, F. N. (2010) To see the visually controlled: Seeing-drawing in formal and informal contexts, Trondheim: Norwegian University of Science and Technology Faculty of Social Sciences and Technology Management Department of Education.

Туник, Е. Е. (2003) Модифицированные креативные тесты Вильямса, Санкт-Петербург: Речь.

Филиповић, С. (2016) Методичка пракса ликовних педагога, Београд: Факултет ликовних уметности.

Филиповић, С. (2009) Развој схватања о дечјем ликовном стваралаштву и могућностима васпитно-образовног деловања на њега, докторска дисертација: Академија умјетности, Универзитет у Бањој Луци.

Закон о основама система образовања и васпитања (2013) 
Службени гласник РС, бр. 72/2009, 52/2011 и 55/2013.

Wilson, B. and Wilson, M. (1977) An iconoclastic view of the imagery sources in the drawing of oung people, Art Education, 1, pp. 5-11.

Sanja B. Filipović and Vesna Janjević Popović

University in Belgrade, Faculty of Fine Arts - Arts Theory Department; Serbian Association of Psychologists, Belgrade

\title{
IMPACT OF INITIAL EDUCATION ON THE PROFESSIONAL COMPETENECES OF TEACHERS- ARTISTS AND ARTISTS-TEACHERS IN TEACHING ARTS
}

\begin{abstract}
Starting from different curriculums of art faculties and teaching colleges, as well as the competences future teachers gain in their study programs, the impact of various factors is analysed, like the impact of initial education on the level of creativity of teaching and divergent creative thinking or artistic/form-related aspects seen in drawings etc. Established facts are then correlated to the competences of teachers/artists (artists who teach art in schools) and teachers/ non-artists (teachers of other subjects) for the realization of teaching and educational objectives, tasks and contents of arts as a primary school subject, as well as to the possible consequences on the creative development of pupils. Research was carried out on a sample of three hundred and thirty-two (332) teachers from thirteen (13) Serbian cities. Characteristics of creative, divergent thinking were monitored based on indicators taken from a standardized research instrument called Modified Creative Williams Test (Tunik 2005), while for the monitoring of artistic and form-related aspects of drawings, a special instrument was created. Based on differences which appear in characteristics of the artistic expression and depending on the initial art education i.e. art pedagogy, statistically significant differences were identified between these two populations, pointing to the need to establish new hypothesis, especially by further researching competences of teaching staff in fulfilling primary objectives of Arts as a teaching subject, and especially researching their impact on creative development of primary school pupils as well as initial education and gaining competences for teaching specific subjects like art.
\end{abstract}

Key words: teacher, initial education, teaching art, art pedagogy, creativity 